\title{
Prolonged cultivation of hippocampal neural precursor cells shifts their differentiation potential and selects for aneuploid cells
}

Article

Published Version

Nguyen, T. D., Widera, D., Greiner, J., Müller, J., Martin, I., Slotta, C., Hauser, S., Kaltschmidt, C. and Kaltschmidt, B. (2013) Prolonged cultivation of hippocampal neural precursor cells shifts their differentiation potential and selects for aneuploid cells. Biological chemistry, 394 (12). pp. 1623-1636. ISSN 1437-4315 doi: https://doi.org/10.1515/hsz-2013-0191 Available at https://centaur.reading.ac.uk/39520/

It is advisable to refer to the publisher's version if you intend to cite from the work. See Guidance on citing.

To link to this article DOI: http://dx.doi.org/10.1515/hsz-2013-0191

Publisher: De Gruyter

All outputs in CentAUR are protected by Intellectual Property Rights law, including copyright law. Copyright and IPR is retained by the creators or other copyright holders. Terms and conditions for use of this material are defined in the End User Agreement. 


\section{www.reading.ac.uk/centaur}

\section{CentAUR}

Central Archive at the University of Reading

Reading's research outputs online 
The Duy Nguyen ${ }^{a}$, Darius Widera ${ }^{a}$, Johannes Greiner, Janine Müller, Ina Martin, Carsten Slotta, Stefan Hauser, Christian Kaltschmidt and Barbara Kaltschmidt*

\section{Prolonged cultivation of hippocampal neural precursor cells shifts their differentiation potential and selects for aneuploid cells}

\begin{abstract}
Neural precursor cells (NPCs) are lineagerestricted neural stem cells with limited self-renewal, giving rise to a broad range of neural cell types such as neurons, astrocytes, and oligodendrocytes. Despite this developmental potential, the differentiation capacity of NPCs has been controversially discussed concerning the trespassing lineage boundaries, for instance resulting in hematopoietic competence. Assessing their in vitro plasticity, we isolated nestin ${ }^{+} / \mathrm{Sox}^{+}$, NPCs from the adult murine hippocampus. In vitro-expanded adult NPCs were able to form neurospheres, self-renew, and differentiate into neuronal, astrocytic, and oligodendrocytic cells. Although NPCs cultivated in early passage efficiently gave rise to neuronal cells in a directed differentiation assay, extensively cultivated NPCs revealed reduced potential for ectodermal differentiation. We further observed successful differentiation of long-term cultured NPCs into osteogenic and adipogenic cell types, suggesting that NPCs underwent a fate switch during culture. NPCs cultivated for more than 12 passages were aneuploid (abnormal chromosome numbers such as 70 chromosomes). Furthermore, they showed growth factor-independent proliferation, a hallmark of tumorigenic transformation. In conclusion, our findings substantiate the lineage restriction of NPCs from adult mammalian hippocampus. Prolonged cultivation results, however, in enhanced differentiation potential, which may be attributed to transformation events leading to aneuploid cells.
\end{abstract}

Keywords: cellular transformation; hippocampus; neural precursor cells; neural stem cells; stem cell plasticity.

These authors contributed equally to this work.

*Corresponding author: Barbara Kaltschmidt, Molecular Neurobiology, Department of Cell Biology, Faculty of Biology, University of Bielefeld, Universitätsstrasse 25, D-33501 Bielefeld, Germany, e-mail: barbara.kaltschmidt@uni-bielefeld.de The Duy Nguyen, Janine Müller, Ina Martin, Carsten Slotta and Stefan Hauser: Molecular Neurobiology, Department of Cell Biology, Faculty of Biology, University of Bielefeld, Universitätsstrasse 25, D-33501 Bielefeld, Germany
Darius Widera, Johannes Greiner and Christian Kaltschmidt: Department of Cell Biology, Faculty of Biology, University of Bielefeld, Universitätsstrasse 25, D-33501 Bielefeld, Germany

\section{Introduction}

In the last decades, neural stem cells (NSCs) gained increasing interest as cells being responsible for adult neurogenesis and participating in tissue homeostasis in the mammalian brain. The importance of understanding identity and function of NSCs today has been elevated by their prospective application for treatment of neurological diseases in the human system.

Defined as self-renewing, multipotent cells that give rise to most cell types of the central nervous system (CNS), NSCs were first successfully isolated by Reynolds and Weiss (1992) in the early 1990s from adult mouse brain tissue. Nowadays, NSCs are commonly known to primarily reside within the subventricular zone (SVZ) of the lateral ventricle (Palmer et al., 1997). As a second prominent region, the subgranular zone of the hippocampal dentate gyrus was also shown to contain NSCs (Palmer et al., 1997), although more recent studies show evidence of hippocampal NSCs being neuronal precursors (NPCs) due to their lineage-restricted differentiation capability and limited capacity to self-renew (Seaberg and van der Kooy, 2002; Bull and Bartlett, 2005). Despite these two well-known regions, NPCs have also been detected in other regions of the mammalian CNS, namely the adult spinal cord and the subcallosal zone of the brain (Weiss et al., 1996; Seri et al., 2006). Concerning their in vivo function, NPCs have been proven to modify CNS tissue homeostasis by giving rise to neurons that can integrate into stable neural circuits (Cameron and McKay, 2001; Imielski et al., 2012). In the adult mammalian brain, such generation of functional neurons was shown under normal conditions upon physiological stimuli or after injury (reviewed by Ma et al., 2009). In the adult 
hippocampus, NPCs participate in adult neuronal plasticity by generation of newborn neurons (Imielski et al., 2012).

Besides the broad range of studies focusing on in vivo characterization, NSCs have been well studied in vitro as cell clusters called 'neurospheres' (Reynolds and Weiss, 1992; Gritti et al., 1996, 1999). Notably, a single NSC was also shown to exhibit the ability to form new neurospheres under appropriate medium conditions and give rise to both neurons and glial cells, suggesting the selfrenewal capability and multipotency of NSCs (Morshead et al., 1994; Bonaguidi et al., 2008). Next to differentiation into their developmentally expected derivatives, NSCs were reported to trespass lineage boundaries, e.g., resulting in hematopoietic cell progeny or skeletal myotubes (Bjornson et al., 1999; Galli et al., 2000).

From the viewpoint of a cell simply changing its phenotype due to extracellular signals, the concept of plasticity has been altered over the last years. Today's understanding of plasticity can be summarized as the shift of an undifferentiated but developmentally restricted cell toward another type of terminal differentiation (Wagers and Weissman, 2004; reviewed by Bonfanti et al., 2012). Adult stem cells from different sources than the CNS have also been shown to exhibit an extraordinary high developmental plasticity (Krause et al., 2001; Wagers et al., 2002), although this phenomenon is suggested to be associated with either spontaneous cell fusion or genomic abnormalities (Terada et al., 2002; Ying et al., 2002; Wang et al., 2003). In this regard, the potential plasticity of NSCs is also discussed controversially (Morshead et al., 2002; Clarke and van der Kooy, 2011), particularly with respect to their endogenous origin from one of the most quiescent tissues of the mammalian body.

In this study, we successfully isolated nestin/Sox2 ${ }^{+}$ neural progenitor cells (NPCs) from the adult murine hippocampus. Hippocampal NPC cultures were able to selfrenew and gave rise to $\beta$-III-tubulin-expressing neuronal cells, glial fibrillary acidic protein (GFAP)-positive astrocytes, and oligodendrocytes expressing 04. Although early-passage NPCs (passage 1-6) efficiently differentiated into neurons and oligodendrocytes in a directed differentiation assay, long-term cultivated NPCs revealed a reduced potential for ectodermal differentiation but successfully gave rise to osteogenic and adipogenic cell types. Extensively cultured NPCs (passage $>12$ ) also exhibited growth factor-independent proliferation and abnormal chromosome numbers, suggesting that the observed fate switch may be caused by transformation events occurring during culture.

\section{Results}

\section{Adult hippocampal neural precursor cells can be efficiently cultivated as monolayer and show the ability to form neurospheres}

Isolated cells from the mouse hippocampus were cultured on poly-D-lysine and laminin-coated surface in NPC medium containing the growth factors EGF and FGF-2 (see Figure 1A). In general accordance with the findings by (Seaberg and van der Kooy, 2002), neural precursor cells (NPCs) began to grow adherently after 2 weeks. Proliferating adherent NPCs homogenously exhibited characteristic elongated bipolar morphology with oval nuclei (Figure 1B) (Conti et al., 2005). After reaching about $80 \%$ confluency, cells could be harvested and passaged, followed by further cultivation in an adherent manner. Proving their NPC characteristics in the first place (Babu et al., 2007), NPCs were shown to form neurospheres under appropriate culture conditions (Figure 1C).

\section{NPC cultures homogeneously express neural precursor markers while lacking expression of neural crest and mesenchymal stem cell markers}

Isolated NPCs in early passage $(<7)$ were characterized using immunocytochemical staining revealing high expression of neural stem cell marker nestin $(98.0 \pm 1.3 \%$, Figure 2A) and NPC marker Olig2 ( $80.4 \pm 1.6 \%, 100 \%$, Figure 2B). In accordance to these observations, only few cells were immunoreactive for differentiation markers $\beta$-III-tubulin (neuronal cells, $1.35 \pm 0.08 \%$, data not shown), glial fibrilary acidic protein (GFAP) (glial cells, 3.0 \pm 0.5 , Figure $2 \mathrm{C}$ ), and 04 (oligodendrocytes, $7.6 \pm 0.9 \%$, data not shown), suggesting the presence of a small subpopulation of spontaneously differentiated NPCs. Moreover, immunocytochemical staining demonstrated no expression of alpha smooth muscle actin ( $\alpha$ SMA) (data not shown). Reverse transcription PCR (RT-PCR) analysis substantiated nestin expression in NPCs, further demonstrating the message of typical neural precursor and NSC markers Sox2, Sox9, Sox10, brain lipid-binding protein (BLBP), sonic hedgehog (SHH), vimentin, and Pax6 (Figure 2D). Because Sox10 is also known to be expressed in neural crest-derived stem cells (NCSCs) (reviewed by Kaltschmidt et al., 2012), we tested the potential expression of a further NCSC-specific transcription factor Snail and found no expression in cultivated NPCs (Figure 2D). To exclude potential contamination with mesenchymal stem cell (MSC) populations such as the recently described 
A
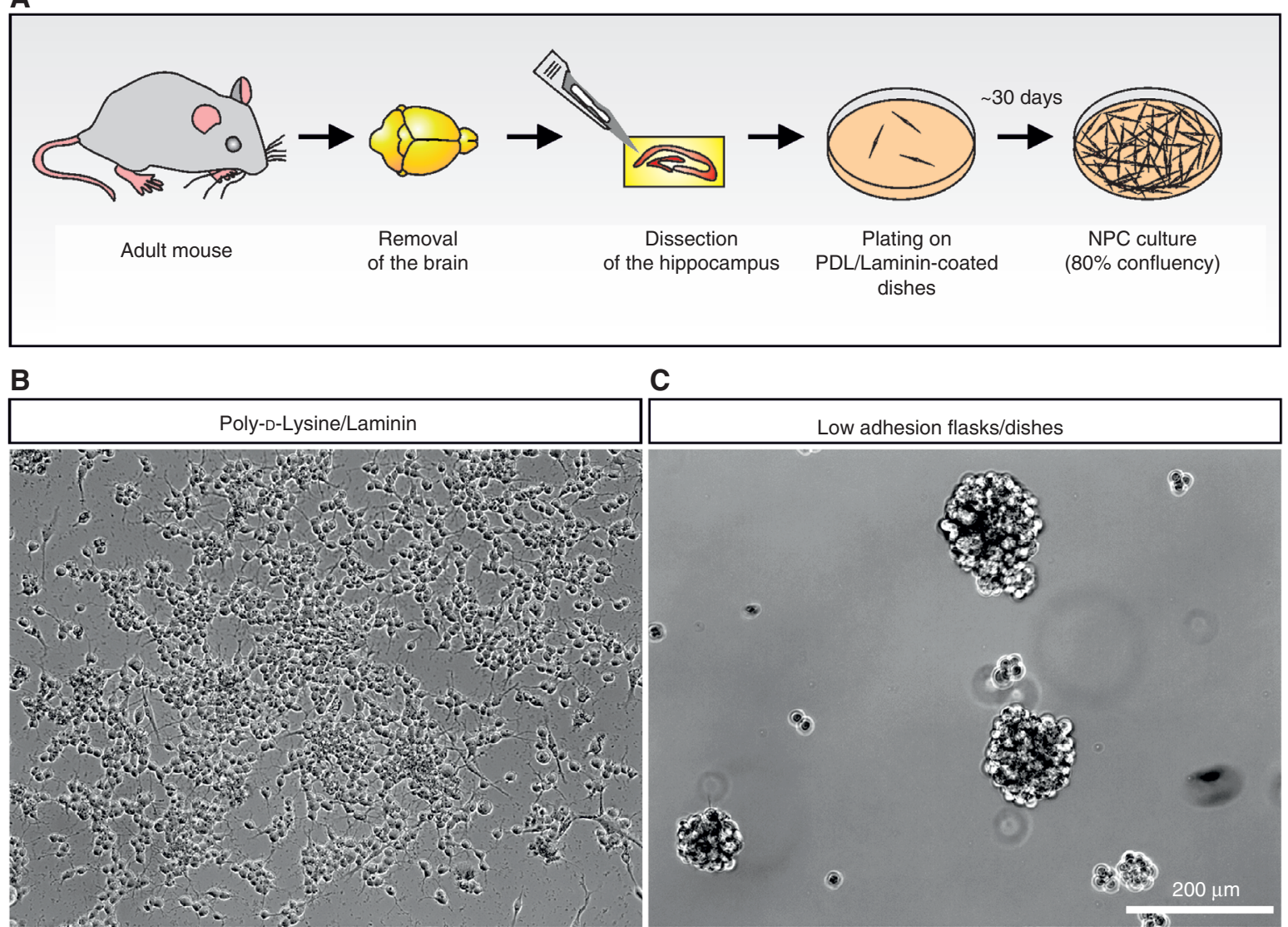

\section{C}

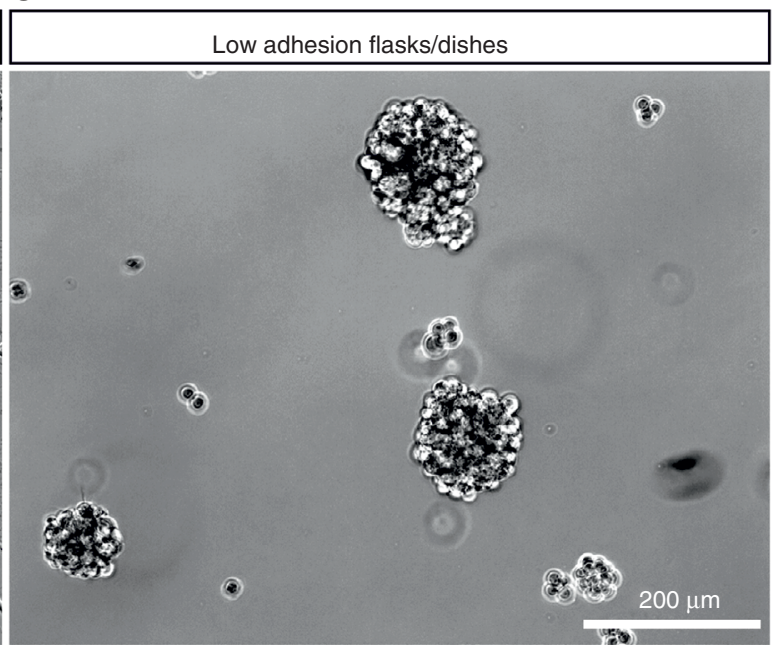

Figure 1 (A) Schematic diagram of the cultivation procedure.

Hippocampi were carefully isolated and mechanically and enzymatically dissociated followed by cultivation of the resulting suspension on poly-D-lysine/laminin-coated cell culture dishes. NPCs cultivated adherently reach $80 \%$ confluency after at least 30 days. (B) Phase contrast image of NPCs cultivated adherently on poly-D-lysine/laminin in presence of EGF and FGF-2 showing typical neural progenitor cell morphology. (C) Phase contrast image of adult hippocampus-derived neurospheres using uncoated, low adhesion flasks.
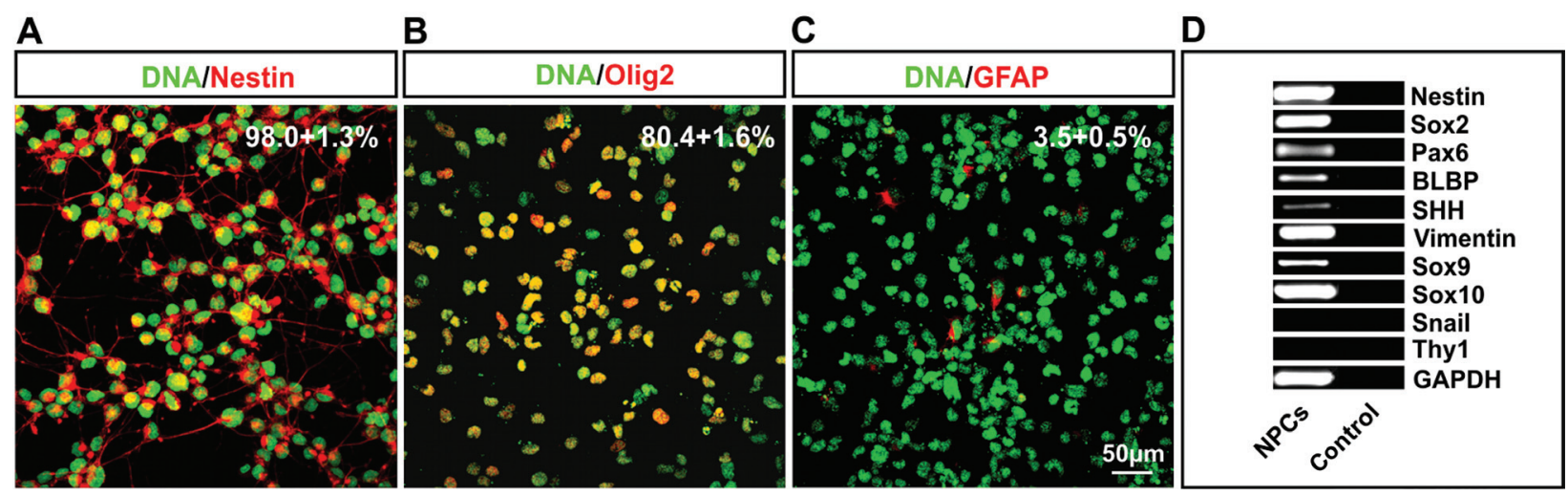

Figure 2 Characterization of cultivated NPCs.

(A, B) NPs cultures express neural precursor markers. Adherently grown NPCs were fixed and stained against the neural stem cell-specific intermediate filament nestin and neural precursor marker Olig2. DNA was counterstained using SYTOX green. Nestin was expressed in $98.0 \pm 1.3 \%$ of NPCs, whereas Olig2 was expressed in $80.4 \pm 1.6 \%$ of NPCs. (C) Small subpopulations of NPCs showed expression of GFAP (3.0 \pm 0.5$)$. (D) RT-PCR analysis demonstrated expression of characteristic neural precursor markers nestin, Sox2, Sox9, Sox10, BLBP, SHH, vimentin, and Pax6, whereas neural crest stem cell-specific transcription factor Snail as well as MSC marker Thy1 were not detectable. Nontemplate approaches served as controls. 
perivascular MSCs (Paul et al., 2012), we assured the absence of MSC-marker Thy1 (Figure 2D) in NPC cultures.

\section{Early-passage NPCs give rise to neuronal, glial, and oligodendrocytic cell types}

Determining the differentiation capability of NPCs, a spontaneous differentiation assay was used by applying
DMEM/F-12 medium containing 10\% fetal calf serum (FCS). Immunocytochemical stainings revealed expression of differentiation markers $\beta$-III-tubulin (neuronal cells, $10.63 \pm 1.59 \%$ ), GFAP (glial cell, $25.70 \pm 2.23 \%$ ), and 04 (oligodendrocytes, $27.28 \pm 0.47 \%$ ) in spontaneously differentiated NPCs (Figure 3A), which was significantly increased compared with undifferentiated control approach. Differentiated NPCs further revealed significantly decreased expression of the NSC marker nestin $(17.04 \pm 0.55 \%)$ and

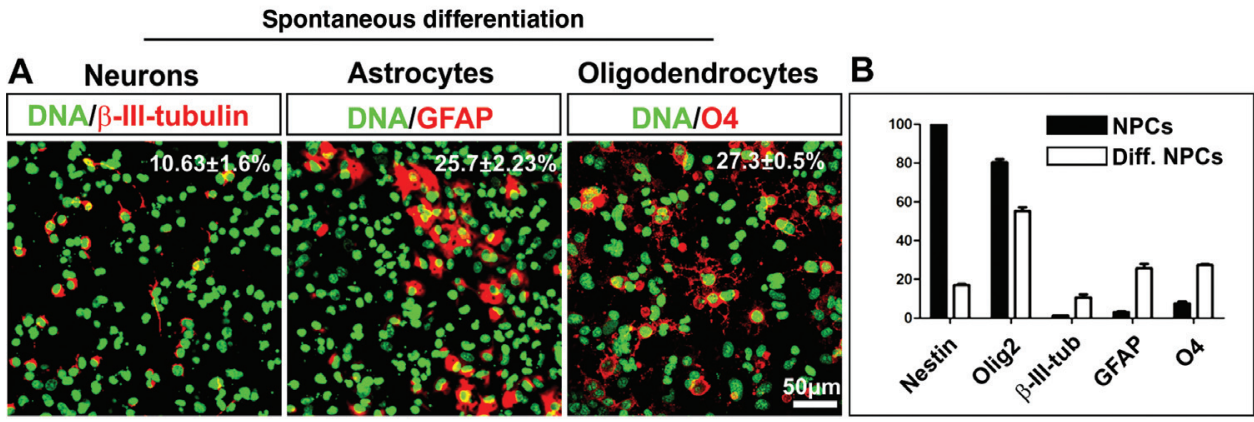

C

RA-induced neuronal differentiation
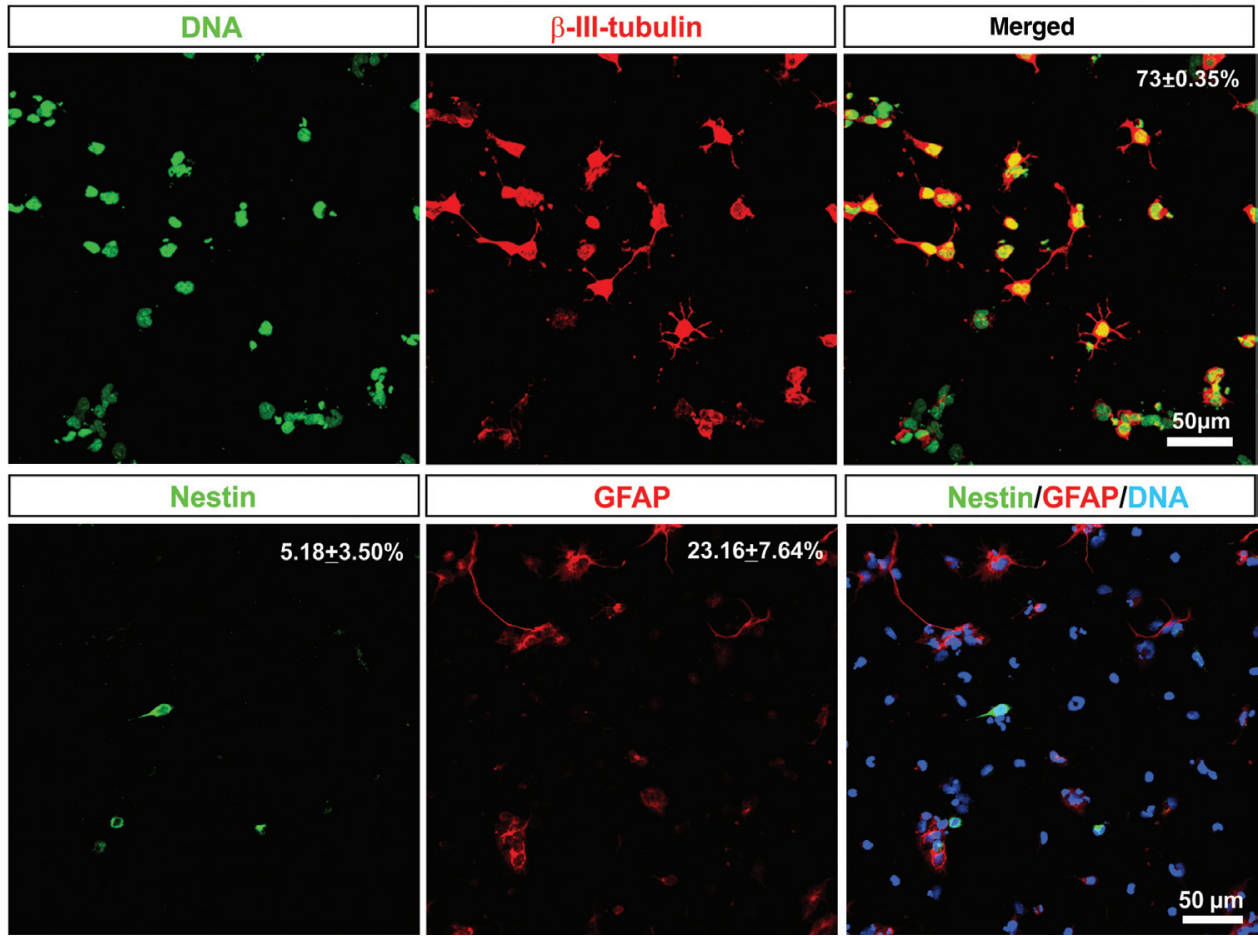

Figure 3 Early-passage NPCs give rise to neuronal, glial, and oligodendrocytic cells.

(A) NPCs undergo differentiation into neuronal, glial, and oligodendrocytic cells. After cultivation for 7 days in the presence of FCS, NPCs were fixed and immunocytochemically stained against neuronal, glial, and oligodendrocyte markers. Confocal microscopy reveals change in morphology in numerous cells after differentiation and the presence of $\beta$-III-tubulin-positive neuronal cells, GFAP-expressing glia, and 04-positive oligodendrocyte-like cells. (B) Statistical evaluation reveals significantly deceased percentage of nestin-positive cells and increase of differentiation markers, namely $10.63 \pm 1.59 \%$ of $\beta$-III-tubulin positive cells, $25.70 \pm 2.23 \%$ of GFAP-expressing cells, and $27.28 \pm 0.47 \%$ of 04 immunoreactive cells. (C) NPCs reveal pronounced neuronal differentiation potential. NPCs were subjected to directed neuronal differentiation in the absence of growth factors and presence of $5 \mu \mathrm{M}$ retinoic acid. Immunocytochemical staining revealed a highly increased percentage of $\beta$-III-tubulin-expressing cells $(73 \pm 0.35 \%)$, whereas the amount of cells expressing nestin was decreased $(5.18 \pm 3.50 \%)$ and the percentage of GFAP-positive cells only slightly changed (23.16 $\pm 7.64 \%$ ) compared with spontaneously differentiated NPCs. 
the NPC marker Olig2 (55.24 $\pm 1.90 \%)$, as shown by statistical evaluation of ICC analysis (Figure 3B).

Although NPCs showed only a low capability in spontaneously increasing neurons $(10.63 \pm 1.59 \%)$, a directed neuronal differentiation assay resulted in $73 \%$ of $\beta$-IIItubulin immunoreactive neuronal cells, indicating a high neuronal differentiation potential. We also observed a further decrease in the amount of nestin-expressing cells $(5.18 \pm 3.50 \%)$, whereas the percentage of GFAP-positive cells was found to be only slightly changed (23.16 $\pm 7.64 \%)$ in comparison to spontaneously differentiated NPCs (Figure 3C).

\section{Extensively cultivated NPCs reveal reduced potential for ectodermal differentiation}

As the differentiation capability of a precursor cell is suggested to be changeable during culture (Morshead et al., 2002), we assessed the presence of respective differentiation markers in high-passage NPCs ( $>25)$ in a spontaneous differentiation assay. In comparison to early-passage NPCs (passage 4), significantly decreased differentiation into $\beta$-III-tubulin-positive neuronal cells and 04-expressing oligodendrocytes was observed in extensively cultivated NPCs. On the contrary, the percentage of undifferentiated nestin- and Olig2-positive NPCs was found to be increased within the passage 26 culture, whereas the amount of GFAP-expressing glial cells seemed unaffected (Figure 4A).

\section{Early- and late-passage NPCs were able to give rise to early osteogenic cells under directed differentiation conditions}

Further investigating the differentiation potential of latepassage NPCs, we assessed a potential crossing of germ layer boundaries by applying a directed differentiation assay into the osteogenic lineage. Broadly described to commonly induce osteogenic differentiation of MSCs (Jaiswal et al., 1997), the respective differentiation medium comprised dexamethasone, $\beta$-glycerophosphate, and L-ascorbic acid-2-phosphate. Here, early- and latepassage NPCs were found to give rise to early osteogenic cell types in a directed differentiation assay, indicated by changes in morphology from bipolar to cuboidal after 10 days of induction as well as by alkaline phosphatase (ALP) activity (data not shown, Figure 4B). These findings suggest a slightly enhanced plasticity of NPCs even in early passages. Although NPCs of all passages showed ALP activity, the amount of ALP-active cells was found to be significantly lower in early-passage NPCs in comparison to late-passage NPCs (p26) (see Figure 4C).

\section{Long-term cultured NPCs spontaneously gave rise to $\alpha$ SMA-positive mesodermal as well as $\beta$-catenin-expressing pre-endodermal cells}

Contrary to directed osteogenic differentiation conditions, we observed the presence of mesodermal $\alpha \mathrm{SMA}$ expressing cells in a spontaneous differentiation assay (in the presence of 10\% FCS) in late-passage NPCs (Figure 4D), whereas early-passage NPCs showed no differentiation into $\alpha$ SMA-positive progeny (data not shown). In accordance to these findings, a small subset of spontaneously differentiated late-passage NPCs showed expression of $\beta$-catenin, an early endodermal marker (Sinner et al., 2004). We observed the presence of such $\beta$-cateninpositive cells again exclusively in differentiated late-passage NPCs (Figure 4D), in contrast to early-passage NPCs lacking $\beta$-catenin expression under the same differentiation conditions (data not shown).

\section{Prolonged culture of NPCs results in enhanced osteogenic and adipogenic differentiation potential under specific differentiation conditions}

To further determine potential effects of long-term culture on the plasticity of NPCs, we applied the directed osteogenic differentiation assay over a longer period. After exposure of high-passage NPCs to osteogenic differentiation medium for 10 days, we again observed changed cellular morphology from bipolar to cuboidal as well as ALP activity, suggesting a phenotype switch into immature osteoblast-like cells. NPCs osteogenically differentiated for 20 days further displayed calcium deposition as shown by intense Alizarin Red and von Kossa signal, whereas untreated controls showed no positive signals (Figure 5A). Importantly, no Alizarin Red and von Kossa-positive cells were founds in early-passage NPCs after 20 days of osteogenic differentiation (data not shown). RT-PCR analysis further substantiated osteogenic differentiation of long-term cultured NPCs by revealing expression of two specific bone matrix proteins osteopontin and osteonectin (Figure 5B).

Investigating the differentiation capacity of long-term cultured NPCs into mesenchymal cell types in more detail, we applied a directed adipogenic differentiation methods 


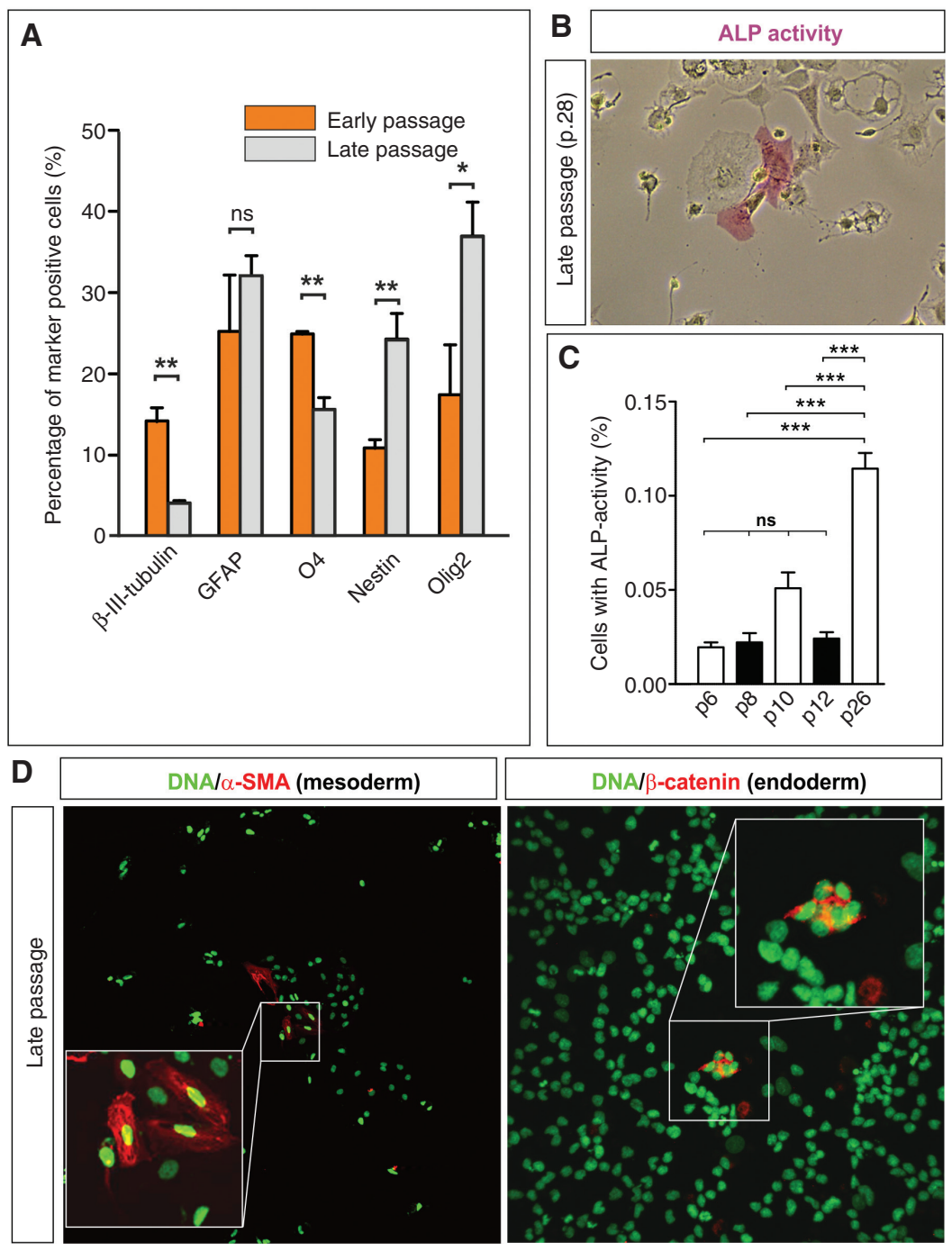

Figure 4 Long-term cultured NPCs show reduced potential for neuronal and oligodendrocytic differentiation but acquire capacity for mesodermal and early endodermal differentiation.

(A) Quantification of respective ICC stainings of spontaneously differentiated NPCs at passage 4 and passage 26 . Passage 26 cultures show decreased differentiation into of $\beta$-III-tubulin-expressing neurons and $\mathrm{O4}^{+}$, while keeping the expression of NPC markers nestin and Olig2.

(B) Late-passage NPCs give rise to early osteogenic cell types in directed differentiation assay, as shown by changed morphology from bipolar to cuboidal after 10 days of induction as well as ALP activity. (C) Quantification of respective ALP activity stainings of directly differentiated NPCs. NPCs of all passages show ALP activity, although the amount of ALP-active cells is significantly lower in early-passage NPCs in comparison to late-passage NPCs. (D) Long-term cultured NPCs acquire the ability to differentiate spontaneously toward mesodermal, $\alpha \mathrm{SMA}$-expressing as well as endodermal, $\beta$-catenin-positive cells. ${ }^{*} p<0.05,{ }^{\star \star} p<0.005,{ }^{* \star *} p<0.001$.

developed for differentiation of MSCs (Janderova et al., 2003). Although a high degree of cell death was observed in NPC cultures during the differentiation assay (data not shown), few NPCs were shown to form Oil Red O-positive lipid droplets, suggesting their conversion into pre-adipogenic cells (Figure 5C). On the contrary, no Oil Red O-positive lipid droplets were observed in early-passage NPCs applied to the same differentiation conditions (data not shown). In accordance to these findings, we observed the expression of adipocyte marker lipoprotein lipase using RT-PCR in differentiated NPCs (Figure 5D).

\section{Long- and intermediate-term cultured NPCs show aberrant chromosome numbers, whereas no abnormal karyotype was observed in early passages}

Because fate switches crossing germ-layer boundaries are suggested to be associated with transformation events during in vitro culture (Morshead et al., 2002), we further assessed karyotypes of cultivated NPCs in early and late passages. As shown in Figure 6A, control 

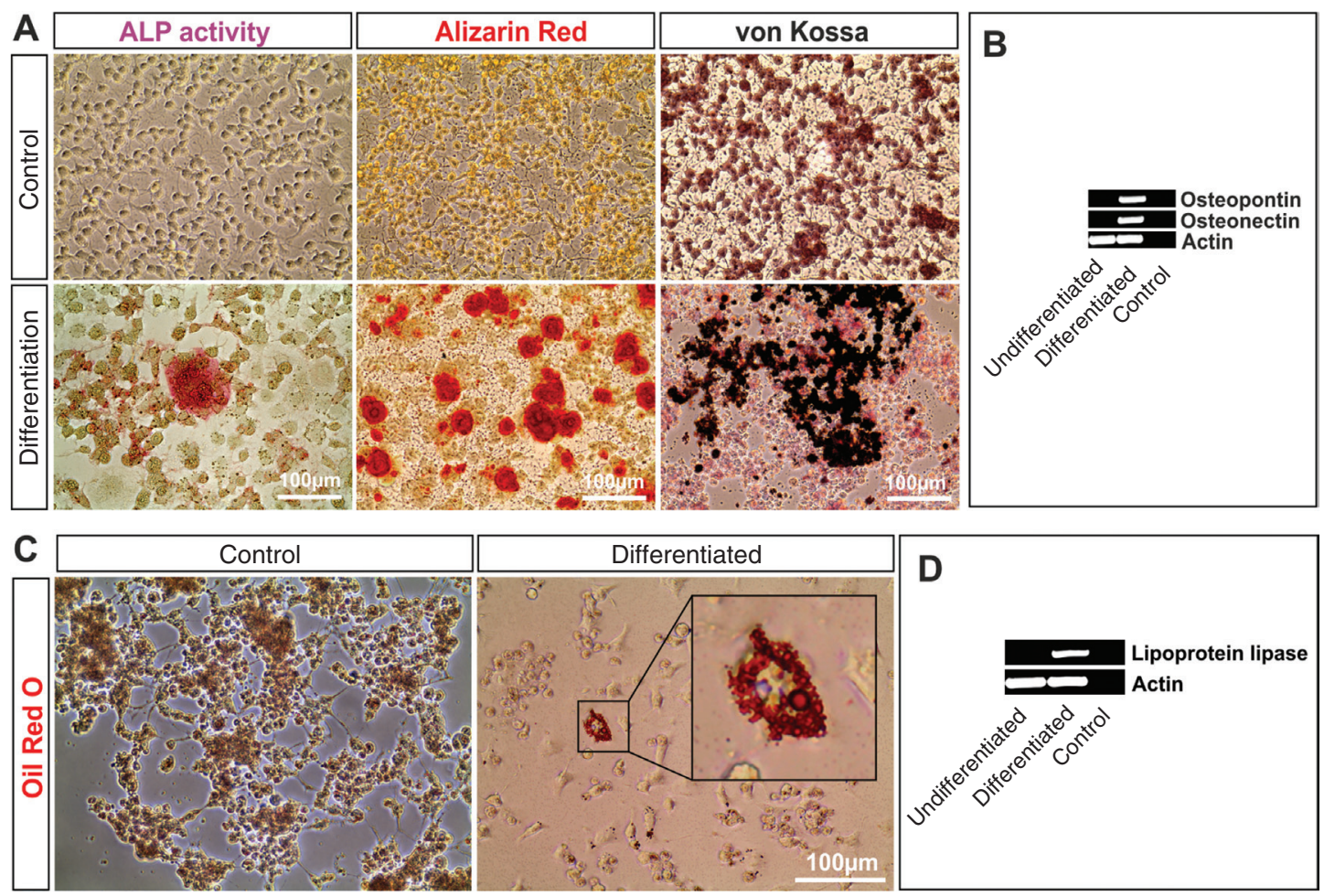

Figure 5 Long-term cultivated NPCs reveal enhanced osteogenic and adipogenic differentiation potential.

(A and B) High-passage NPCs give rise to late osteogenic cell types. NPCs pre-cultivated as monolayer were osteogenically induced by application of medium containing dexamethasone, glycerophosphate, and L-ascorbic acid-2-phosphate. (A) Directed osteogenic differentiation resulted in changed morphology from bipolar to cuboidal after 10 days of induction as well as ALP activity. After 20 days of induction, Alizarin Red S and Von Kossa stainings demonstrated calcium depositions only in osteogenically induced approaches. (B) RT-PCR analysis revealed induction of osteogenic markers osteopontin and osteonectin in induced NPCs and no marker expression in undifferentiated controls. Actin was used as housekeeping gene, whereas non-template approaches served as controls. (C and D) Extensively cultivated NPCs can differentiate into adipogenic cells. Adherently pre-cultivated NPCs were adipogenically induced using medium containing insulin, 3-isobutyl-1-methylxanthine, dexamethasone (1 $\mu \mathrm{M}$; Sigma-Aldrich), and indomethazine. (C) Twenty-one days after induction, cells were stained using Oil Red O, demonstrating lipid droplets in adipogenically induced NPCs, whereas no positive signal was seen in undifferentiated cells. (D) RT-PCR analysis confirmed the results of Oil Red $O$ staining, as only adipogenically induced cells expressed the adipogenic enzyme lipoprotein lipase at the mRNA level.

mouse embryonic fibroblasts (MEFs) and passage 6 NPCs showed normal karyotypes comprising 40 chromosomes. In contrast, NPCs cultivated up to passages 8, 10, 12, 19, and 27 revealed highly abnormal karyotypes, for instance, $68.5 \pm 1.8$ chromosomes in passage 27 NPCs (Figure 6B).

\section{Extensively cultivated NPCs grow independently of EGF and FGF-2 without changes in clonal efficiency}

In addition to the aneuploidy of long-term cultured NPCs during prolonged culture, we observed the formation of abnormal worm-like spherical structures in NPCs cultivated up to passage 27 under neurosphere conditions. In contrast, passage 6 NPCs revealed normal capability of sphere formation (Figure 6C) with round, densely packed neurospheres. Because such structures may be associated with enhanced growth capacities due to transformation events, we investigated potential differences in clonal growth between passage 6 and passage 27 NPCs. Longterm cultivated NPCs revealed no significantly changed clonal efficiency (Figure 6D) and proliferation capability, as depicted by no significant changes in total cell numbers between NPCs of passage $7(2.11 \mathrm{E}+05 \pm 4.76 \mathrm{E}+04$ cells), passage $13(2.40 \mathrm{E}+05 \pm 4.09 \mathrm{E}+04$ cells $)$ and passage $22(2.12 \mathrm{E}+05 \pm 4.15 \mathrm{E}+04$ cells $)$ after $96 \mathrm{~h}$ of cultivation. Extensively cultured NPCs were shown to grow independently to growth factors FGF-2 and EGF (Figure 6E). 
A

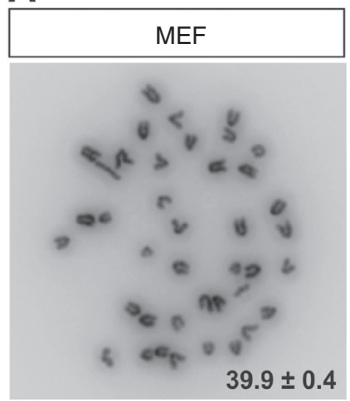

B

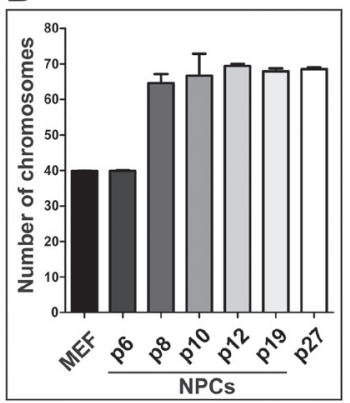

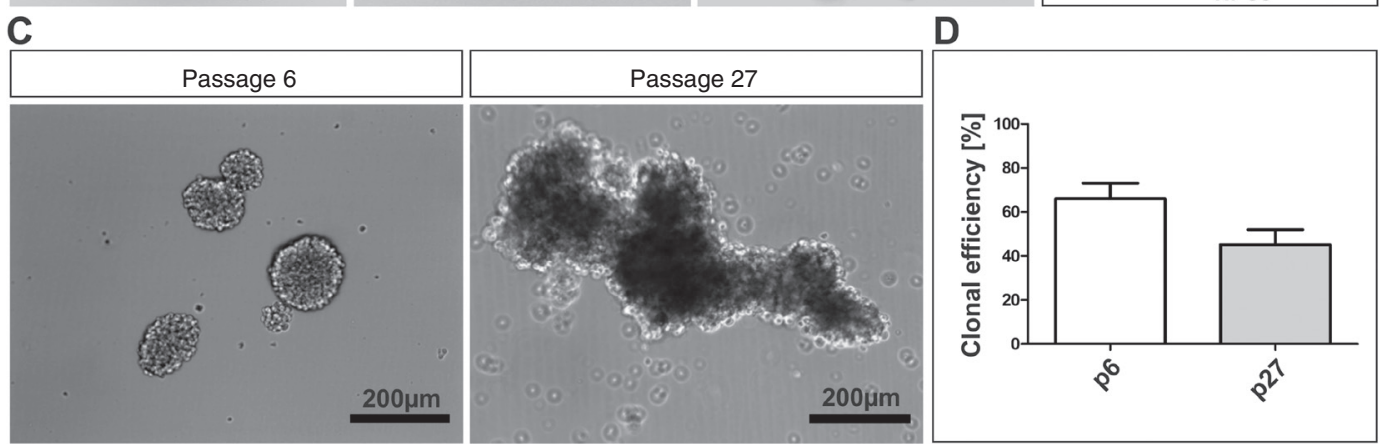
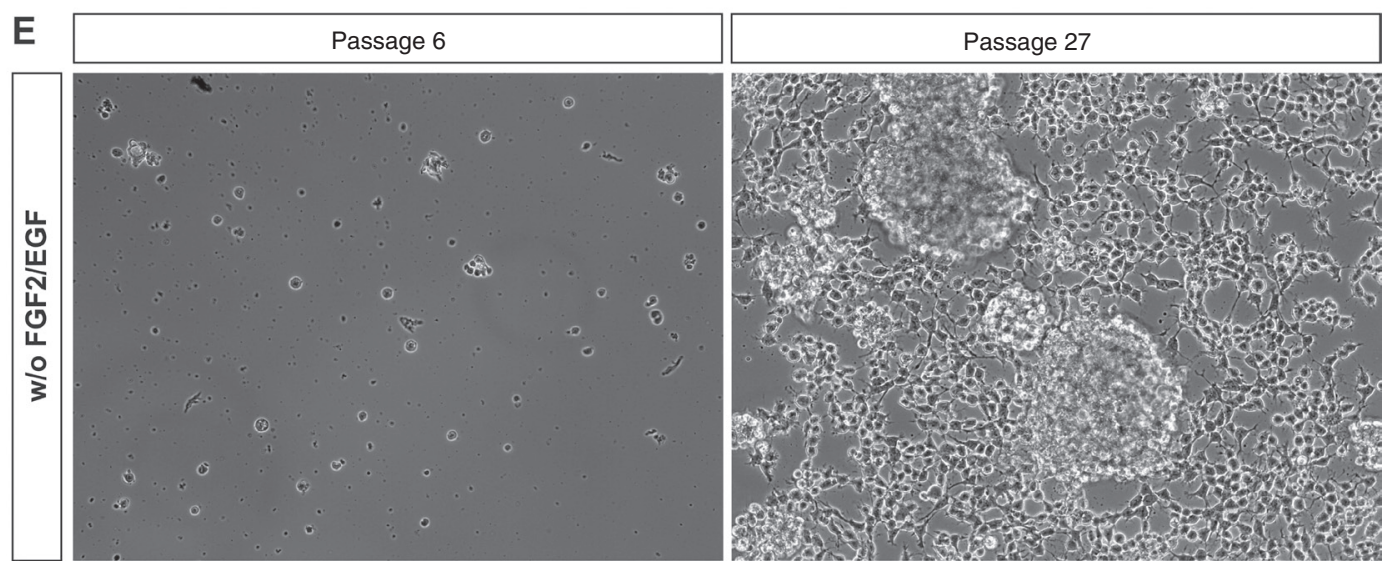

Figure 6 Extensively cultivated NPCs show highly increased chromosome numbers and grow independent to growth factors.

(A) Long- and intermediate-term cultured PNCs show abnormal karyotype. Phase contrast picture of isolated chromosomes revealed normal karyotypes (39.9 \pm 0.4 ) in MEF as well as passage 6 NPCs (39.9 \pm 0.5 chromosomes, passage 6), whereas NPCs cultivated up to passage 27 revealed highly abnormal karyotypes (68.5 \pm 1.8 chromosomes, NPCs/p27). (B) Summarizing diagram shows respective chromosome numbers of NPCs cultivated up to passage $6,8,10,12,19$, and 27 , revealing highly abnormal exclusively in passage 12,19 , and 27 PNCs $(n=30)$. (C) Phase contrast picture of NPC-derived neurospheres from passage 6 and passage 27 cultures. Passage 27 NPCs formed abnormal worm-like spherical structures, whereas neurospheres derived from passage 6 NPCs showed normal, densely packed, regular neurosphere structure. (D) The percentage of NPC clones showing capability of secondary sphere formation. Long-term cultivated NPC clones revealed no significantly changed clonal efficiency in comparison to passage 6 NPCs. (E) Phase contrast picture of NPCs in early and late passage, showing FGF-2- and EGF-independent growth at passage 27.

\section{Discussion}

This study demonstrates for the first time a change of in vitro plasticity in adult murine NPCs, which is associated closely with transformation events occurring during long-term culture. In particular, we demonstrate a dramatic reduction in neuronal and oligodendrocytic differentiation capacity and acquisition of mesodermal differentiation in late-passage NPCs.

With respect to their origin within the CNS, neural stem cells and precursor cells have been broadly described to possess the ability of differentiating into neurons, astrocytes, and oligodendrocytes (Reynolds and Weiss, 1992; Morshead et al., 1994; Gritti et al., 1996). Surprisingly, 
adult NSCs and NPCs were described to harbor an extraordinary high degree of plasticity, suggested by trespassing of lineage restrictions. NSCs were shown to give rise to skeletal muscle cells by direct exposure to myoblasts (Galli et al., 2000) as well as to melanocytes, chondrocytes, and smooth muscle cells in co-culture with quail neural crest cells (Alexanian and Sieber-Blum, 2003). Wurmser et al. (2004) extended these reports by demonstrating the differentiation of NSCs into endothelial cells in vitro, evidenced by stable expression of respective markers and the capacity to form capillary networks.

Moreover, in vitro-cultivated NSCs were described to undergo differentiation into cells of all germ layers after injection into the chicken and mouse blastocyst, thereby contributing to the formation of chimeric embryos (Clarke et al., 2000). Transplantation of cultivated, genetically labeled NSCs into irradiated hosts was further suggested to result in differentiation into a broad range of blood cell types (Bjornson et al., 1999). On the contrary, the said differentiation capacity was questioned only 3 years later by Morshead et al. (2002), demonstrating no sign of NSCderived hematopoietic cell types in 128 host animals after intravenous injection of NSCs. The authors also observed changes in growth properties, growth factor dependence, and cell cycle kinetics in cultured neurosphere cells, thereby assuming that the fate switch reported by Bjornson et al. (1999) may be due to rare transformation events (Morshead et al., 2002).

In case of adult stem cells, such transformation events are commonly known to be associated with prolonged in vitro culture (Izadpanah et al., 2008; reviewed by Widera et al., 2008; Rosland et al., 2009). With respect to neural stem cells, Wu et al. (2011) reported spontaneous malignant transformation of human NSCs cultured over an extended period (passage 17). Subsequent transplantation of transformed human NSCs into nude mice led to the formation of xenografts expressing neuroendocrine tumor markers, whereas a xenograft-derived cell line showed abnormal karyotype and enhanced proliferation. Stem cells from the adult rat SVZ were likewise shown to transform into tumorigenic cell lines after their expansion in vitro, as demonstrated by multiple acquired chromosomal aberrations and malignant tumor formation after syngeneic transplantation into the brain of adult rats (Siebzehnrubl et al., 2009). As reported by Kaus et al. (2010), long-term culture of adult rat NSCs not only results in aberrant, aneuploid DNA contents, and malignant tumor formation after in vivo transplantation but also in cell growth independent to exogenous growth factors. Substantiating these findings, we observed abnormal chromosome numbers as well as growth factor-independent proliferation in NPCs from murine adult hippocampus after long- and intermediate-term culture.

Long-term culture of NPCs did not only result in cellular transformation but also in enhanced plasticity, particularly including successful differentiation of long-term cultivated NPCs into adipogenic and late osteogenic cell types. Besides this enhanced potential for mesodermal differentiation, we also observed a reduced ectodermal differentiation capacity in long-term cultivated NPCs. These findings are in accordance to several studies demonstrating a reduced potential of long-term cultured NPCs to undergo ectodermal differentiation (Bull and Bartlett, 2005; Louis et al., 2008). Our findings further indicate a slightly enhanced plasticity of NPCs even in early passages, a phenomenon revealed by the extraordinary high neuronal differentiation potential as well as the capability to give rise to early osteogenic cell types. However, in our hands, early-passage NPCs never gave rise to late osteogenic cell types and showed a lower potential to differentiate into early ones compared with late-passage NPCs. In addition, early-passage NPCs did not differentiate spontaneously into mesodermal and endodermal cell types. Given these data, we suggest that although fate switches may occur in early passages, their severity is highly increased during prolonged cultivation. In accordance to our further findings, fate switches are broadly associated with transformation events (Morshead et al., 2002; Terada et al., 2002; Ying et al., 2002; Lotem and Sachs, 2006), although a direct link between the osteogenic and adipogenic differentiation potential of NPCs and the transformation events associated with in vitro culture has not been described so far.

In vivo, a chromosome-specific accumulation of aneuploidy has been recently demonstrated with a frequency of $50 \%$ in aged mouse brain (Faggioli et al., 2012). However, because the NPCs described here showed normal karyotype in early passage, the aneuploidy shown in our study seems to be selected by prolonged culture.

In conclusion, we demonstrate here for the first time that cultivation of adult murine hippocampal NPCs is closely associated with cell fate switches from neuronal and oligodendrocytic toward the mesodermal lineage as well as aberrant karyotypes and growth factor-independent proliferation.

Our findings particularly emphasize the potential relevance of transformation events concerning the investigation of cellular plasticity of NPCs and NSCs. Moreover, this study undelines the importance of rigid quality control of the stem cells for basic research as well as for potential clinical use. 


\section{Materials and methods}

\section{Isolation of NPCs from adult mouse hippocampus}

All tissue was extracted according to local (Bezirksregierung Düsseldorf) and international guidelines. In particular, adult 129/ BL6 or C57/BL6 mice (between 2 and 4 months age) were killed by cervical dislocation. Complete brains were immediately removed. Hippocampi were carefully separated from the adjacent tissue, dissected, and chopped into small fragments using surgical disposable scalpels (Aesculap, Malsungen, Germany) and placed in ice-cold 1× HBSS (Life Technologies, Darmstadt, Germany) supplemented with 15 mm HEPES (pH 7.5; PAA, Pasching, Austria), D-glucose (5.4 mg/ml; Sigma-Aldrich, Munich, Germany), amphotericin B (1:100; PAA), and penicillin/streptomycin (1:100; PAA). Further stem cell-isolation procedure from the dissected tissue was performed as described by Widera et al. (2006).

\section{Cultivation of NPCs}

The cell suspension was plated on poly-D-lysine/laminin-coated dishes (for the coating protocol, see Martin et al., 2012) in serumfree DMEM/F12 (Biochrom AG, Berlin, Germany) supplemented with EGF (20 ng/ml; R\&D Systems, Wiesbaden, Germany), FGF-2 (40 ng/ ml; laboratory made), $3 \times$ NS21/B27 supplement (Chen et al., 2008), and heparin ( $0.5 \mathrm{U} / \mathrm{ml}$; Sigma-Aldrich) and subsequently cultivated at $37^{\circ} \mathrm{C}, 5 \% \mathrm{CO}_{2}$, and $5 \% \mathrm{O}_{2}$ until confluency of $\sim 80 \%$ (at least for 30 days) with medium change every 2 days. Passaging was performed using Accutase (PAA) at $37^{\circ} \mathrm{C}$ for 15 min with subsequent cultivation as monolayer or as neurosphere cultures. For neurosphere cultivation, uncoated low-adherence $25-\mathrm{cm}^{2}$ Tissue Culture Flasks (Greiner Bio One, Frickenhausen, Germany) were used. Spheres were dissociated using Accutase at $37^{\circ} \mathrm{C}$ for $15 \mathrm{~min}$.

\section{Limited dilution assay}

Limited dilution assay was used to examine the clonal efficiency of NPCs as described by Widera et al. (2009). In particular, NPCs were collected and dissociated as described above. Afterward, the dissociated cells were diluted to 1 cell/100 $\mu \mathrm{l}$ and placed into 96-well, roundbottom microtiter plates in NPC medium. Four hours after plating, 384 wells were analyzed for the presence of single cells. Newly forming neurospheres were examined regularly using inverse microscopy (AMG EVOS xl; PeqLab, Erlangen, Germany) over a period of 1 month.

\section{Immunocytochemistry}

Cells were fixed with 4\% paraformaldehyde (PFA; Sigma-Alrich) for $20 \mathrm{~min}$ at room temperature (RT), followed by three wash steps with $1 \times$ PBS and permeabilization with $0.02 \%$ Triton X-100 (SigmaAldrich). Blocking was achieved using $5 \%$ of appropriate normal serum (Dianova, Hamburg, Germany) for 30 min at RT followed by incubation with primary antibodies (see Table 1). After three
Table 1 List of primary antibodies used for ICC.

\begin{tabular}{|c|c|c|c|}
\hline Antibody & $\begin{array}{l}\text { Species } \\
\text { of origin }\end{array}$ & Dilution & Provider \\
\hline $\begin{array}{l}\text { Anti-nestin clone rat-401 } \\
\text { monoclonal antibody }\end{array}$ & Mouse & $1: 100$ & Millipore \\
\hline Anti-nestin & Rabbit & $1: 300$ & Covance \\
\hline Anti-Olig2 polyclonal antibody & Rabbit & $1: 500$ & Millipore \\
\hline Polyclonal rabbit anti-GFAP & Rabbit & $1: 300$ & Dako \\
\hline Anti- $\beta$-III-tubulin & Mouse & $1: 300$ & Promega \\
\hline Anti-04 & Mouse & $1: 50$ & Millipore \\
\hline$\beta$-Catenin & Mouse & $1: 100$ & $\begin{array}{l}\text { Developmental } \\
\text { Studies } \\
\text { Hybridoma } \\
\text { Bank }\end{array}$ \\
\hline $\begin{array}{l}\text { Monoclonal anti-smooth } \\
\text { muscle actin }\end{array}$ & Mouse & $1: 50$ & Sigma-Aldrich \\
\hline
\end{tabular}

wash steps using $1 \times$ PBS, secondary antibodies were applied for $1 \mathrm{~h}$ at RT in the dark. The following secondary antibodies were used including Alexa Fluor 555 goat anti-mouse (A21422; 1:300; Life Technologies), Alexa Fluor 555 goat anti-rabbit (A21428; 1:300; Life Technologies), and Alexa Fluor 555 goat anti-mouse IgM ( $\mu$ chain, A21426, 1:300; Molecular Probes/Life Technologies). Subsequently, the cells were washed three times with $1 \times$ PBS and the DNA was counterstained with SYTOX green (1:10,000; Life Technologies) supplemented with RNAse A $(500 \mathrm{U} / \mathrm{ml}$; Thermo/Fermentas, St. Leon-Rot, Germany) followed by mounting using in Mowiol (Carl Roth). For $\mathrm{O} 4$ surface antigen staining, cells were washed in PBS supplemented with $0.1 \%$ bovine serum albumin followed by 20-min incubation with primary antibody. Afterward, cells were washed with $1 \times$ PBS and fixed for 15 min in 4\% PFA. Secondary antibodies were applied as described above. Fluorescence imaging was performed using confocal laser scanning microscopy (LSM 510; Carl Zeiss).

\section{Reverse transcription PCR}

Total RNA was purified using RNeasy Mini Kit or RNeasy Micro Kit (Qiagen, Hilden, Germany) according to the manufacturer's guidelines. The RNA concentration was measured and qualified with Nanodrop UV spectrophotometry (Peqlab). cDNA was generated using First Strand cDNA Synthesis Kit (Thermo/Fermentas) according to the manufacturer's guidelines. PCR was performed using KAPA2G Robust PCR Kit (Peqlab) according to the manufacturer's guidelines. For primer sequences, see Table 2 .

\section{Spontaneous differentiation}

For spontaneous differentiation assay, cells were seeded at a density of $1 \times 10^{5}$ cells/well onto 18 -mm coverslips, placed in a 12-well plate, and cultured in DMEM/F-12 supplemented with $\mathrm{P} / \mathrm{S}$, amphotericin B, and 10\% FCS (Sigma-Aldrich). Cultivation was performed for at least 10 days at $37^{\circ} \mathrm{C}, 5 \% \mathrm{CO}_{2}$, and atmospheric $\mathrm{O}_{2}$ in a humidified incubator. The quantification was performed after immunocytochemical 
Table 2 List of primers used for RT-PCR.

\begin{tabular}{|c|c|c|c|}
\hline Primer & Sequence $\left(5^{\prime} \rightarrow 3^{\prime}\right)$ & $\begin{array}{r}\text { Annealing } \\
\text { temperature }\left({ }^{\circ} \mathrm{C}\right)\end{array}$ & $\begin{array}{r}\text { Produc } \\
\text { size (bp) }\end{array}$ \\
\hline$\beta$-Actin forward & GAG AAG ATG ACC CAG ATC ATG T & 57 & 333 \\
\hline$\beta$-Actin reverse & САT CTC TTG CTC GAA GTC CAG & & \\
\hline$\beta$-III-tubulin forward & AAC CAG ATA GGG GCC AAG TT & 58 & 221 \\
\hline$\beta$-III-tubulin reverse & GGC CTG AAT AGG TGT CCA AA & & \\
\hline GAPDH forward & CTG CAC CAC CAA CTG CTT AG & 60 & 108 \\
\hline GAPDH reverse & GTC TTC TGG GTG GCA GTG AT & & \\
\hline GFAP forward & GAG ATC GCC ACC TAC AGG AA & 60 & 331 \\
\hline GFAP reverse & GCA CAC CTC ACA TCA CAT CC & & \\
\hline Lipoprotein lipase forward & GCG TAG CAG GAA GTC TGA CC & 63 & 421 \\
\hline Lipoprotein lipase reverse & CTA CAA CTC AGG CAG AGC CC & & \\
\hline Nestin forward & GAT CGC TCA GAT CCT GGA AG & 60 & 118 \\
\hline Nestin reverse & AGG TGT CTG CAA GCG AGA GT & & \\
\hline Osteonectin forward & AAA CAT GGC AAG GTG TGT GA & 63 & 217 \\
\hline Osteonectin reverse & TGC ATG GTC CGA TGT AGT C & & \\
\hline Osteopontin forward & TCT GAT GAG ACC GTC ACT GC & 63 & 170 \\
\hline Osteopontin reverse & AGG TCC TCA TCT GTG GCA TC & & \\
\hline Snail forward & TGG AAA GGC CTT CTC TAG GC & 60 & 148 \\
\hline Snail reverse & CTT CAC ATC CGA GTG GGT TT & & \\
\hline Sox2 forward & ACT TTT GTC CGA GAC CGA GA & 60 & 149 \\
\hline Sox 2 reverse & CTC CGG GAA GCG TGT ACT TA & & \\
\hline Sox10 forward & ATG TCA GAT GGG AAC CCA GA & 60 & 190 \\
\hline Sox10 reverse & TTA CCT CGT GGC TGA TCT CC & & \\
\hline Sox9 forward & TGA AGA AGG AGA GCG AGG AA & 60 & 351 \\
\hline Sox9 reverse & GGG GCT GGT ACT TGT AAT CG & & \\
\hline Thy1 forward & GGG CGA CTA CTT TTG TGA GC & 59 & 164 \\
\hline Thy1 reverse & GGA GGA GGG AGA GGG AAA G & & \\
\hline Vimentin forward & GTG GAC CAG CTA ACC AAC GAC AAA & 64 & 314 \\
\hline Vimentin reverse & AGG TCA GGC TTG GAA ACA TCC ACA & & \\
\hline
\end{tabular}

staining for the respective marker using ImageJ software (NIH, Bathesda, MD, USA) and statistically evaluated using GraphPad Prism (GraphPad Software, La Jolla, CA, USA) (Student's $t$-test).

\section{Directed neuronal differentiation}

For directed neuronal differentiation, cells were seeded at a density of $2 \times 10^{5}$ cells/well on PDL/laminin-coated 18 -mm coverslips placed in a 12-well plate and pre-cultured for $48 \mathrm{~h}$ in NPC medium supplemented with $5 \mu \mathrm{M}$ retinoic acid (Sigma-Aldrich). Afterward, the medium was switched to growth factor-free Neurobasal medium (Life Technologies) supplemented with $5 \mu \mathrm{m}$ retinoic acid. Further cultivation was performed for at least 7 days at $37^{\circ} \mathrm{C}, 5 \% \mathrm{CO}_{2}$, and atmospheric $\mathrm{O}_{2}$ in a humidified incubator.

\section{Osteogenic differentiation}

For osteogenic differentiation, cells were seeded at a density of $1 \times 10^{5}$ in DMEM high glucose (PAA) supplemented with $\mathrm{P} / \mathrm{S}$, amphotericin B, 10\% FCS, $100 \mathrm{~nm}$ dexamethasone (Sigma-Aldrich), $10 \mathrm{~mm} \beta$-glycerophosphate (Sigma-Aldrich), and $0.05 \mathrm{~mm} \mathrm{~L}$-ascorbic acid-2-phosphate (Sigma-Aldrich). Osteogenic differentiation was detected by determination of ALP activity after 10 days and histochemical stainings as well as PCR analysis after 20 days of differentiation.

\section{Adipogenic differentiation}

For adipogenic differentiation, cells were seeded at a density of $1 \times 10^{5}$ in DMEM high glucose (PAA) supplemented with $\mathrm{P} / \mathrm{S}$, amphotericin B, 10\% FCS, insulin ( $2 \mu \mathrm{M}$; Sigma-Aldrich), 3-isobutyl-1-methylxanthine (500 $\mu \mathrm{M}$; Sigma-Aldrich), dexamethasone (1 $\mu \mathrm{M}$; SigmaAldrich), and indomethacin (200 $\mu$; Sigma-Aldrich). After 8 days, adipogenic induction medium was completely removed and changed to regeneration medium composed of DMEM high glucose, 10\% FCS and $2 \mu \mathrm{M}$ insulin for 2 days. Cells were treated in this manner for 21 days. Adipogenic differentiation was assessed via Oil Red O staining and RT-PCR analysis.

\section{Detection of ALP activity}

After 10 days of differentiation, ALP activity in osteogenically induced NPCs was detected by using the Alkaline Phosphatase Detection Kit (Millipore) according to the manufacturer's guidelines. 


\section{Alizarin Red S staining}

After 20 days of differentiation, cells were fixed with 4\% PFA for $15 \mathrm{~min}$. After removal of fixation solution, cells were washed two times with $\mathrm{ddH}_{2} \mathrm{O}$. Alizarin Red S staining solution (Waldeck $\mathrm{GmbH}$ ) was incubated for $5 \mathrm{~min}$ at RT followed by rinsing with $\mathrm{ddH}_{2} \mathrm{O}$. Staining was visualized using AMG EVOS xl inverse microscope (Peqlab).

\section{Von Kossa staining}

After 20 days of differentiation, cells were fixed with 4\% PFA for $15 \mathrm{~min}$ and washed two times with $\mathrm{ddH}_{2} \mathrm{O}$ followed by incubation with $5 \%$ silver nitrate solution (Fluka Chemie AG) under ultraviolet light for $60 \mathrm{~min}$ followed by two wash steps with $\mathrm{ddH}_{2} \mathrm{O}$. Subsequently, $5 \%$ sodium thiosulfate solution (resolved in $\mathrm{ddH}_{2} \mathrm{O}$; Fluka Chemie AG) was applied for $3 \mathrm{~min}$. Unreacted silver was removed followed by two wash steps with $\mathrm{ddH}_{2} \mathrm{O}$ and counterstaining for 5 min with Kernechtrot solution (100 ml dd $\mathrm{d}_{2} \mathrm{O}, 5 \mathrm{~g}$ aluminum sulfate, and $0.1 \%$ Kernechtrot; Merck, Darmstadt, Germany). Cells were washed once with $100 \%$ ethanol then twice with $96 \%$ ethanol. Staining was visualized with AMG EVOS xl inverse microscope (Peqlab).

\section{Oil Red 0 staining}

The medium was completely removed followed by two wash steps with $\mathrm{ddH}_{2} \mathrm{O}$. Afterward, cells were fixed with $10 \%$ PFA for $1 \mathrm{~h}$ at RT. Oil Red O staining solution was prepared with three parts from Oil Red O Stock solution (0.5\% Oil Red O resolved in isopropanol; SigmaAldrich) and 2 parts $\mathrm{ddH}_{2} \mathrm{O}$. The mixture was filtered two times using Whatman paper to remove precipitates. Oil Red O staining solution was applied to the cells and incubated for $2 \mathrm{~h}$ at RT. The solution was subsequently removed and cells were washed two times with $\mathrm{ddH}_{2} \mathrm{O}$. Staining was visualized using inverse microscopy AMG EVOS $\mathrm{xl}$ inverse microscope (Peqlab).

\section{References}

Alexanian, A.R. and Sieber-Blum, M. (2003). Differentiating adult hippocampal stem cells into neural crest derivatives. Neuroscience 118, 1-5.

Babu, H., Cheung, G., Kettenmann, H., Palmer, T.D., and Kempermann, G. (2007). Enriched monolayer precursor cell cultures from micro-dissected adult mouse dentate gyrus yield functional granule cell-like neurons. PLoS One 2, e388.

Bjornson, C.R., Rietze, R.L., Reynolds, B.A., Magli, M.C., and Vescovi, A.L. (1999). Turning brain into blood: a hematopoietic fate adopted by adult neural stem cells in vivo. Science 283, 534-537.

Bonaguidi, M.A., Peng, C.Y., McGuire, T., Falciglia, G., Gobeske, K.T., Czeisler, C., and Kessler, J.A. (2008). Noggin expands neural stem cells in the adult hippocampus. J. Neurosci. 28, 9194-9204.

Bonfanti, P., Barrandon, Y., and Cossu, G. (2012). 'Hearts and bones': the ups and downs of 'plasticity' in stem cell biology. EMBO Mol. Med. 4, 353-361.

\section{Preparation of NPCs metaphase chromosomes}

Metaphase chromosomes of NPCs were prepared according as described by Kaus et al. (2010). In particular, $1 \times 10^{7} \mathrm{NPC}$ of respective passages (p6, p12, p19, and p27) as well as MEFs were metaphase-arrested, treated with pre-warmed hypotonic solution, and progressively fixed in methanol/acetate. For chromosome spreading, the suspension was dropped onto coverslips and air dried. Staining of chromosomes was done using DAPI (50 ng/ml).

\section{Proliferation assay of cultivated NPCs}

Defined numbers of passage 7, passage 13, and passage 22 NPCs were cultivated in NPC medium for 4 days. Total cell numbers were determined after dissociation using Accutase at $37^{\circ} \mathrm{C}$ for $15 \mathrm{~min}$. GraphPad Prism was applied for statistical analysis of cell proliferation (GraphPad Software, La Jolla, CA, USA).

Acknowledgments: We thank Angela Kralemann-Köhler and Vivien Krell for the excellent technical help and Timo Schomann, Lena-Marie Grunwald, and Ilse Betzendahl for the karyotyping. Experimental work described herein that was performed in our laboratory was supported by a grant of University of Bielefeld to D.W., grants of the German Research Council (DFG) to C.K., and a grant of the German Ministry of Research and Education (BMBF) to B.K. The $\beta$-catenin monoclonal antibody developed by J. Balsamo and J. Lilien was obtained from the Developmental Studies Hybridoma Bank developed under the auspices of the NICHD and maintained by the Department of Biology, University of Iowa, Iowa City, IA, USA.

Received May 24, 2013; accepted September 27, 2013; previously published online October 1, 2013

Bull, N.D. and Bartlett, P.F. (2005). The adult mouse hippocampal progenitor is neurogenic but not a stem cell. J. Neurosci. 25, 10815-10821.

Cameron, H.A. and McKay, R.D. (2001). Adult neurogenesis produces a large pool of new granule cells in the dentate gyrus. J. Comp. Neurol. 435, 406-417.

Chen, Y., Stevens, B., Chang, J., Milbrandt, J., Barres, B.A., and Hell, J.W. (2008). NS21: re-defined and modified supplement B27 for neuronal cultures. J. Neurosci. Methods 171, 239-247.

Clarke, L. and van der Kooy, D. (2011). The adult mouse dentate gyrus contains populations of committed progenitor cells that are distinct from subependymal zone neural stem cells. Stem Cells 29, 1448-1458.

Clarke, D.L., Johansson, C.B., Wilbertz, J., Veress, B., Nilsson, E., Karlstrom, H., Lendahl, U., and Frisen, J. (2000). Generalized potential of adult neural stem cells. Science 288, 1660-1663. 
Conti, L., Pollard, S.M., Gorba, T., Reitano, E., Toselli, M., Biella, G., Sun, Y., Sanzone, S., Ying, Q.L., Cattaneo, E., et al. (2005). Niche-independent symmetrical self-renewal of a mammalian tissue stem cell. PLoS Biol. 3, e283.

Faggioli, F., Wang, T., Vijg, J., and Montagna, C. (2012). Chromosome-specific accumulation of aneuploidy in the aging mouse brain. Hum. Mol. Genet. 21, 5246-5253.

Galli, R., Borello, U., Gritti, A., Minasi, M.G., Bjornson, C., Coletta, M., Mora, M., De Angelis, M.G., Fiocco, R., Cossu, G., et al. (2000). Skeletal myogenic potential of human and mouse neural stem cells. Nat. Neurosci. 3, 986-991.

Gritti, A., Parati, E.A., Cova, L., Frolichsthal, P., Galli, R., Wanke, E., Faravelli, L., Morassutti, D.J., Roisen, F., Nickel, D.D., et al. (1996). Multipotential stem cells from the adult mouse brain proliferate and self-renew in response to basic fibroblast growth factor. J. Neurosci. 16, 1091-1100.

Gritti, A., Frolichsthal-Schoeller, P., Galli, R., Parati, E.A., Cova, L., Pagano, S.F., Bjornson, C.R., and Vescovi, A.L. (1999). Epidermal and fibroblast growth factors behave as mitogenic regulators for a single multipotent stem cell-like population from the subventricular region of the adult mouse forebrain. J. Neurosci. 19, 3287-3297.

Imielski, Y., Schwamborn, J.C., Luningschror, P., Heimann, P., Holzberg, M., Werner, H., Leske, O., Puschel, A.W., Memet, S., Heumann, R., et al. (2012). Regrowing the adult brain: NF- KB controls functional circuit formation and tissue homeostasis in the dentate gyrus. PLoS One 7, e30838.

Izadpanah, R., Kaushal, D., Kriedt, C., Tsien, F., Patel, B., Dufour, J., and Bunnell, B.A. (2008). Long-term in vitro expansion alters the biology of adult mesenchymal stem cells. Cancer Res. 68 , 4229-4238.

Jaiswal, N., Haynesworth, S.E., Caplan, A.I., and Bruder, S.P. (1997). Osteogenic differentiation of purified, culture-expanded human mesenchymal stem cells in vitro. J. Cell. Biochem. 64, 295-312.

Janderova, L., McNeil, M., Murrell, A.N., Mynatt, R.L., and Smith, S.R. (2003). Human mesenchymal stem cells as an in vitro model for human adipogenesis. Obes. Res. 11, 65-74.

Kaltschmidt, B., Kaltschmidt, C., and Widera, D. (2012). Adult craniofacial stem cells: sources and relation to the neural crest. Stem Cell Rev. 8, 658-671.

Kaus, A., Widera, D., Kassmer, S., Peter, J., Zaenker, K., Kaltschmidt, C., and Kaltschmidt, B. (2010). Neural stem cells adopt tumorigenic properties by constitutively activated NF-KB and subsequent VEGF up-regulation. Stem Cells Dev. 19, 999-1015.

Krause, D.S., Theise, N.D., Collector, M.I., Henegariu, O., Hwang, S., Gardner, R., Neutzel, S., and Sharkis, S.J. (2001). Multi-organ, multi-lineage engraftment by a single bone marrow-derived stem cell. Cell 105, 369-377.

Lotem, J. and Sachs, L. (2006). Epigenetics and the plasticity of differentiation in normal and cancer stem cells. Oncogene 25, 7663-7672.

Louis, S.A., Rietze, R.L., Deleyrolle, L., Wagey, R.E., Thomas, T.E., Eaves, A.C., and Reynolds, B.A. (2008). Enumeration of neural stem and progenitor cells in the neural colony-forming cell assay. Stem Cells 26, 988-996.

Ma, D.K., Bonaguidi, M.A., Ming, G.L., and Song, H. (2009). Adult neural stem cells in the mammalian central nervous system. Cell Res. 19, 672-682.
Martin, I., Nguyen, T.D., Krell, V., Greiner, J.F., Muller, J., Hauser, S., Heimann, P., and Widera, D. (2012). Generation of Schwann cell-derived multipotent neurospheres isolated from intact sciatic nerve. Stem Cell Rev. 8, 1178-1187.

Morshead, C.M., Reynolds, B.A., Craig, C.G., McBurney, M.W., Staines, W.A., Morassutti, D., Weiss, S., and van der Kooy, D. (1994). Neural stem cells in the adult mammalian forebrain: a relatively quiescent subpopulation of subependymal cells. Neuron 13, 1071-1082.

Morshead, C.M., Benveniste, P., Iscove, N.N., and van der Kooy, D. (2002). Hematopoietic competence is a rare property of neural stem cells that may depend on genetic and epigenetic alterations. Nat. Med. 8, 268-273.

Palmer, T.D., Takahashi, J., and Gage, F.H. (1997). The adult rat hippocampus contains primordial neural stem cells. Mol. Cell. Neurosci. 8, 389-404.

Paul, G., Ozen, I., Christophersen, N.S., Reinbothe, T., Bengzon, J., Visse, E., Jansson, K., Dannaeus, K., Henriques-Oliveira, C., Roybon, L., et al. (2012). The adult human brain harbors multipotent perivascular mesenchymal stem cells. PLoS One 7, e35577.

Reynolds, B.A. and Weiss, S. (1992). Generation of neurons and astrocytes from isolated cells of the adult mammalian central nervous system. Science 255, 1707-1710.

Rosland, G.V., Svendsen, A., Torsvik, A., Sobala, E., McCormack, E., Immervoll, H., Mysliwietz, J., Tonn, J.C., Goldbrunner, R., Lonning, P.E., et al. (2009). Long-term cultures of bone marrow-derived human mesenchymal stem cells frequently undergo spontaneous malignant transformation. Cancer Res. 69, 5331-5339.

Seaberg, R.M. and van der Kooy, D. (2002). Adult rodent neurogenic regions: the ventricular subependyma contains neural stem cells, but the dentate gyrus contains restricted progenitors. J. Neurosci. 22, 1784-1793.

Seri, B., Herrera, D.G., Gritti, A., Ferron, S., Collado, L., Vescovi, A., Garcia-Verdugo, J.M., and Alvarez-Buylla, A. (2006). Composition and organization of the SCZ: a large germinal layer containing neural stem cells in the adult mammalian brain. Cereb. Cortex 16, i103-i111.

Siebzehnrubl, F.A., Jeske, I., Muller, D., Buslei, R., Coras, R., Hahnen, E., Huttner, H.B., Corbeil, D., Kaesbauer, J., Appl, T., et al. (2009). Spontaneous in vitro transformation of adult neural precursors into stem-like cancer cells. Brain Pathol. 19, 399-408.

Sinner, D., Rankin, S., Lee, M., and Zorn, A.M. (2004). Sox17 and beta-catenin cooperate to regulate the transcription of endodermal genes. Development 131, 3069-3080.

Terada, N., Hamazaki, T., Oka, M., Hoki, M., Mastalerz, D.M., Nakano, Y., Meyer, E.M., Morel, L., Petersen, B.E., and Scott, E.W. (2002). Bone marrow cells adopt the phenotype of other cells by spontaneous cell fusion. Nature 416, 542-545.

Wagers, A.J. and Weissman, I.L. (2004). Plasticity of adult stem cells. Cell 116, 639-648.

Wagers, A.J., Sherwood, R.I., Christensen, J.L., and Weissman, I.L. (2002). Little evidence for developmental plasticity of adult hematopoietic stem cells. Science 297, 2256-2259.

Wang, X., Willenbring, H., Akkari, Y., Torimaru, Y., Foster, M., Al-Dhalimy, M., Lagasse, E., Finegold, M., Olson, S., and Grompe, M. (2003). Cell fusion is the principal source of bone-marrow-derived hepatocytes. Nature 422, 897-901. 
Weiss, S., Dunne, C., Hewson, J., Wohl, C., Wheatley, M., Peterson, A.C., and Reynolds, B.A. (1996). Multipotent CNS stem cells are present in the adult mammalian spinal cord and ventricular neuroaxis. J. Neurosci. 16, 7599-7609.

Widera, D., Mikenberg, I., Kaus, A., Kaltschmidt, C., and Kaltschmidt, B. (2006). Nuclear factor- $\kappa B$ controls the reaggregation of 3D neurosphere cultures in vitro. Eur. Cell. Mater. 11, 76-84; discussion 85.

Widera, D., Kaus, A., Kaltschmidt, C., and Kaltschmidt, B. (2008). Neural stem cells, inflammation and NF- $\mathrm{KB}$ : basic principle of maintenance and repair or origin of brain tumours? J. Cell. Mol. Med. 12, 459-470.

Widera, D., Zander, C., Heidbreder, M., Kasperek, Y., Noll, T., Seitz, O., Saldamli, B., Sudhoff, H., Sader, R., Kaltschmidt, C., et al.
(2009). Adult palatum as a novel source of neural crest-related stem cells. Stem Cells 27, 1899-1910.

Wu, W., He, Q., Li, X., Zhang, X., Lu, A., Ge, R., Zhen, H., Chang, A.E., Li, Q., and Shen, L. (2011). Long-term cultured human neural stem cells undergo spontaneous transformation to tumor-initiating cells. Int. J. Biol. Sci. 7, 892-901.

Wurmser, A.E., Nakashima, K., Summers, R.G., Toni, N., D’Amour, K.A., Lie, D.C., and Gage, F.H. (2004). Cell fusion-independent differentiation of neural stem cells to the endothelial lineage. Nature 430, 350-356.

Ying, Q.L., Nichols, J., Evans, E.P., and Smith, A.G. (2002). Changing potency by spontaneous fusion. Nature 416 , 545-548. 